JURNAL RESPIRASI

JR

Vol. 4 No. 2 Mei 2018

\title{
Hubungan Kadar Periostin Serum dan Nilai Asthma Control Test pada Pasien Asma di RSUD Dr. Soetomo Surabaya
}

\author{
Ni Made Dwita Yaniswari*, Muhammad Amin \\ Departemen Pulmonologi dan Ilmu Kedokteran Respirasi, Fakultas Kedokteran, Universitas Airlangga/RSUD Dr. Soetomo
}

\begin{abstract}
Background: Asthma is a heterogenous disease composed of various phenotype. Chronic airway inflammation are fundamental features of asthma. The main treatment of asthma is corticosteroid. The administration of inhaled corticosteroids will reduce the inflammatory process in asthma. Even with adequate inhaled corticosteroid treatment, there are still patients who develop symptoms with lower asthma control test score. Periostin is an extracellular matrix protein as the best single systemic biomarker for assessing tissue eosinophilia, airway remodeling in uncontrolled asthma. The objective of this study was to examine whether serum periostin is correlated with ACT in asthmatic patients. Methods: This research was an observational analytical with cross sectional design conducted in outpatient clinic Dr. Soetomo General Hospital Surabaya for 3 months. In total, we found 40 asthmatic patients who were qualified to the inclusion and exclusion criteria as the research samples. The questionnaire was filled in to assess the Asthma Control Test and venous blood tests to measure serum periostin levels using Sandwich Enzyme-Linked Immunosorbent Assay (ELISA) method. Results: The mean periostin level profile of the sample was $94.82 \pm 19.21 \mathrm{ng} / \mathrm{ml}$ and the median was $94.7 \mathrm{ng} / \mathrm{ml}$. The average ACT score was $16.55 \pm 2.93$ with $85 \%$ were uncontrolled asthma. The results of the independent t-test showed serum periostin levels and the level of asthma control based on ACT score in asthmatics patients had a significant correlation $(p=0.024)$. Conclusion: There is a significant correlation between serum periostin levels and ACT score in asthmatic patients.
\end{abstract}

Keywords: asthma, periostin, ACT score

Correspondence: Ni Made Dwita Yaniswari, Departemen Pulmonologi dan Ilmu Kedokteran Respirasi, Fakultas Kedokteran, Universitas Airlangga/RSUD Dr. Soetomo. Jl. Mayjen Prof. Dr. Moestopo 6-8 Surabaya 60286. E-mail: dwitayaniswari@ yahoo.com

\section{PENDAHULUAN}

Asma adalah penyakit inflamasi kronik yang melibatkan berbagai sel dan elemen, menyebabkan respons berlebih saluran napas yang ditandai dengan gejala episodik dan berulang dari mengi, sesak napas, dada terasa berat, dan batuk yang terutama terjadi pada malam atau dini hari. Obstruksi saluran napas bersifat bervariasi dan reversible, baik secara spontan maupun dengan pengobatan. ${ }^{1,2}$

Berdasarkan Global Initiative for Asthma (GINA) 2017, jumlah penderita asma di dunia mencapai 300 juta dengan rentang 1-16\% populasi di setiap negara yang berbeda. ${ }^{1}$ Survei Kesehatan Rumah Tangga (SKRT) tahun 2004 menunjukkan bahwa asma menempati urutan ketiga dari 10 penyebab morbiditas di Indonesia. $^{3}$

Tata laksana asma yang utama adalah pemberian anti-inflamasi. Pemberian kortikosteroid inhalasi akan menurunkan proses inflamasi pada asma. Namun, 5-10 $\%$ penderita asma tidak berespons pada terapi, obstruksi saluran napas tetap irreversible dengan tingkat kontrol asma yang dinilai dengan Asthma
Control Test (ACT) yang rendah. ${ }^{4}$ Pada kondisi ini, biasanya sudah terjadi proses remodeling saluran napas dan fibrosis subepitelial. ${ }^{5}$ Fibrosis subepitelial disebabkan oleh penebalan lamina retikularis, terdapat matriks ekstraselular yang terdeposisi di bagian bawah basal lamina. Studi menunjukkan bahwa IL-4 dan IL-13 berperan penting pada fibrosis subepitelial. ${ }^{6,7}$

Masih sedikit biomarker yang dapat menunjukkan inflamasi eosinofil/th2 dan adanya remodeling saluran napas. Studi The Bronchoscopic Exploratory Research Study of Biomarkers in Corticosteroid Refractory Asthma (BOBCAT) oleh Jia dkk mengidentifikasi bahwa periostin dalam serum merupakan biomarker tunggal sistemik yang terbaik untuk menilai eosinofilia jaringan, remodeling saluran napas pada asma tidak terkontrol. ${ }^{8}$ Kegagalan untuk mendeteksi insensitivitas terhadap steroid dapat mempengaruhi strategi terapi dan hasil pengobatan. ${ }^{9}$

Periostin merupakan protein matriks ekstraseluler yang memediasi aktivasi sel dengan cara berikatan pada reseptor di permukaan sel. Periostin diregulasi oleh IL-4, IL-13 dan TGF- $\beta$ serta diproduksi oleh sel struktural 
seperti sel epitel dan fibroblas serta sel inflamasi seperti eosinofil dan makrofag. Periostin berhubungan dengan remodeling saluran napas, produksi mukus, dan fibrosis subepitelial. Terdapat beberapa kelebihan periostin sebagai biomarker. Salah satunya adalah periostin memiliki kecendrungan untuk mudah berpindah dari lesi ke pembuluh darah. ${ }^{9,10}$

Berdasarkan data-data di atas, maka pada penelitian ini peneliti akan menilai hubungan antara kadar periostin serum dan tingkat kontrol asma yang diukur dengan nilai ACT. Hasil penelitian ini diharapkan mampu memberi gambaran tentang fungsi periostin sebagai biomarker untuk memprediksi keberhasilan terapi pada asma.

\section{METODE}

Penelitian ini adalah penelitian analitik observasional dengan rancangan cross sectional di Poli Asma/PPOK RSUD Dr. Soetomo Surabaya yang dimulai pada bulan Maret hingga Mei 2018. Sampel penelitian sejumlah 40 orang adalah penderita asma yang memenuhi kriteria inklusi dan eksklusi. Kriteria inklusi penelitian ini adalah penderita yang telah didiagnosis asma dan kontrol di poli Asma/PPOK RSUD Dr. Soetomo Surabaya, usia 18-55 tahun, telah mendapat kortikosteroid inhalasi selama minimal 3 bulan dan bersedia menandatangani informed consent. Kriteria ekslusi adalah penderita asma dalam serangan, wanita hamil dan menyusui, penderita asma dengan penyakit paru lainnya yang juga dapat menurunkan faal paru seperti tuberkulosis, kanker paru, pneumonia, interstitial lung disease, pneumotoraks, bronkiektasis, batuk darah, atau penyakit kronik lain yang dapat mempengaruhi nilai periostin, seperti penyakit jantung, hati, ginjal, diabetes mellitus, kanker yang dilihat dari dokumen rekam medis, perokok aktif, dan penderita yang sulit bekerja sama dalam penelitian. Dilakukan pemeriksaan spirometri untuk menilai faal paru. Tingkat kontrol asma ditentukan berdasarkan skor ACT dengan asma terkontrol penuh apabila nilai ACT 25, asma terkontrol sebagian dengan nilai ACT 20-24, dan asma tidak terkontrol apabila nilai ACT $\leq 19 .{ }^{11}$ Pemeriksaan darah vena untuk kadar periostin serum dilakukan dengan metode Sandwich ELISA dengan reagen periostin Elisa kit RayBiotech yang dinyatakan dalam satuan ng/ml. Kadar periostin dikelompokkan menjadi tertil I (periostin rendah) dengan kadar $<89,0$ $\mathrm{ng} / \mathrm{ml}$, tertil II (periostin sedang) dengan kadar 89,0 $101,0 \mathrm{ng} / \mathrm{ml}$, serta tertil III (periostin tinggi) dengan kadar $>101,0 \mathrm{ng} / \mathrm{ml}$.

\section{HASIL}

Selama periode penelitian pada bulan Maret Mei 2018, didapatkan 40 penderita asma dengan karakteristik dasar subjek dapat dilihat pada tabel 1 . Jenis kelamin subjek terbanyak adalah perempuan yaitu 26 orang $(65 \%)$ dengan rerata umur 42,25 $\pm 9,9$ tahun. Rerata indeks massa tubuh (IMT) 25,68 $\pm 4,91$ $\mathrm{kg} / \mathrm{m}^{2}$. Profil faal paru didapatkan rerata $\mathrm{FEV}_{1}$ sebesar $61,93 \pm 20,81 \%$ prediksi. Sebanyak 29 subjek dari 40 subjek didapatkan mengalami obstruksi dengan mayoritas masuk dalam derajat obstruksi sedang yaitu 16 orang $(40 \%)$. Pada tingkat kontrol asma didapatkan rerata ACT skor 16,55 \pm 2,93 dengan sebagian besar subyek masuk dalam kelompok asma tidak terkontrol sebanyak 34 orang (85\%) (Tabel 1).

Tabel 1. Karakteristik dasar subjek penelitian

\begin{tabular}{|c|c|}
\hline Karaketristik & Jumlah \\
\hline $\begin{array}{l}\text { Jenis Kelamin } \\
\text { Laki-Laki } \\
\text { Perempuan }\end{array}$ & $\begin{array}{l}14(35 \%) \\
26(65 \%)\end{array}$ \\
\hline $\begin{array}{l}\text { Umur (tahun) } \\
\text { Rerata } \pm \text { Simpangan Baku } \\
\text { Min - Maks }\end{array}$ & $\begin{array}{l}42,25 \pm 9,95 \\
18-55\end{array}$ \\
\hline $\begin{array}{l}\text { Indeks Massa Tubuh }\left(\mathrm{kg} / \mathrm{m}^{2}\right) \\
\text { Rerata } \pm \text { Simpangan Baku } \\
\text { Min - Maks } \\
\end{array}$ & $\begin{array}{l}25,68 \pm 4,91 \\
16,87-40,44\end{array}$ \\
\hline $\begin{array}{l}\text { Tingkat Kontrol Asma } \\
\text { Rerata } \pm \text { Simpangan Baku } \\
\text { Terkontrol Sebagian }(20-24) \\
\text { Tidak Terkontrol }(\leq 19) \\
\end{array}$ & $\begin{array}{l}16,55 \pm 2,935 \\
6(15 \%) \\
34(85 \%) \\
\end{array}$ \\
\hline $\begin{array}{l}\mathrm{FEV}_{1}(\% \text { prediksi) } \\
\text { Rerata } \pm \text { Simpangan Baku } \\
\text { Min }- \text { Maks }\end{array}$ & $\begin{array}{l}61,93 \pm 20,81 \\
18-108\end{array}$ \\
\hline $\begin{array}{c}\text { Kelompok obstruksi }\left(\mathrm{FEV}_{1} / \mathrm{FVC}<75 \%\right) \\
\text { Obstruksi Ringan }\left(\mathrm{FEV}_{1}>80 \%\right) \\
\text { Obstruksi Sedang }\left(\mathrm{FEV}_{1} 50 \%-80 \%\right) \\
\text { Obstruksi Berat }\left(\mathrm{FEV}_{1}<50 \%\right) \\
\end{array}$ & $\begin{array}{l}2(5 \%) \\
16(40 \%) \\
11(27,5 \%) \\
\end{array}$ \\
\hline $\begin{array}{l}\text { Pekerjaan } \\
\text { Ibu Rumah Tangga } \\
\text { Karyawan Swasta } \\
\text { Wiraswasta } \\
\text { Lain-lain } \\
\end{array}$ & $\begin{array}{l}19(47,5 \%) \\
10(25 \%) \\
4(10 \%) \\
7(17,5 \%)\end{array}$ \\
\hline
\end{tabular}

Kadar periostin serum bervariasi, dengan nilai terendah 50,9 $\mathrm{ng} / \mathrm{ml}$ dan nilai tertinggi 138,2 $\mathrm{ng} / \mathrm{ml}$. Rerata kadar periostin serum sebesar 94,82 $\pm 19,21$ $\mathrm{ng} / \mathrm{ml}$ dan nilai median $94,7 \mathrm{ng} / \mathrm{ml}$. Pengelompokkan periostin menggunakan tertil berdasarkan kadar periostin dengan membagi menjadi periostin rendah, sedang, dan tinggi

Tabel 2. Kadar periostin serum

\begin{tabular}{ll}
\hline Periostin (ng/ml) & Jumlah \\
\hline Rerata \pm Simpangan Baku & $94,82 \pm 19,21$ \\
Median & 94,7 \\
Min - Maks & $50,9-138,2$ \\
\hline Kelompok Periostin & \\
\hline Rendah $(<89,0 \mathrm{ng} / \mathrm{ml})$ & $13(32,5 \%)$ \\
Sedang $(89,0-101,0 \mathrm{ng} / \mathrm{ml})$ & $14(35 \%)$ \\
Tinggi $(>101,0 \mathrm{ng} / \mathrm{ml})$ & $13(32,5 \%)$ \\
\hline
\end{tabular}

Perbandingan nilai ACT pada kelompok obstruksi didapatkan bahwa nilai rerata ACT tertinggi didapatkan pada kelompok obstruksi ringan, dan terendah pada kelompok obstruksi berat. Hasil analisis varian menunjukkan perbedaan bermakna nilai ACT antar kelompok ( $\mathrm{p}<0,05)$, selanjutnya dilakukan uji 
lanjut LSD untuk mengetahui kelompok mana yang berbeda. Hasil uji LSD menunjukkan skor ACT ketiga kelompok berbeda.

Tabel 3. Perbandingan nilai ACT menurut kelompok FEV 1

\begin{tabular}{lll}
\hline $\begin{array}{l}\text { Kelompok } \\
\text { Obstruksi }\end{array}$ & $\begin{array}{l}\text { Nilai ACT } \\
(\text { rerata } \pm \text { SD) }\end{array}$ & Nilai p \\
\hline Ringan & $21,50 \pm 0,70$ & \\
Sedang & $17,06 \pm 2,54$ & 0,003 \\
Berat & $14,45 \pm 2,84$ & \\
\hline
\end{tabular}

Perbandingan kadar periostin serum menurut derajat kontrol asma dapat dilihat pada tabel 4 dan gambar 1, rerata kadar periostin serum pada kelompok tidak terkontrol lebih tinggi dibandingkan kelompok terkontrol sebagian. Uji perbandingan kadar periostin serum menggunakan uji independent t-test disebabkan oleh karena sebaran data untuk variabel periostin serum pada tiap kelompok ACT sesuai dengan sebaran normal. Terdapat perbedaan bermakna antara kadar periostin serum penderita dengan asma terkontrol sebagian dibandingkan kadar periostin serum penderita dengan asma tidak terkontrol $(\mathrm{p}<0,05)$.

Tabel 4. Perbandingan kadar periostin serum dan tingkat kontrol asma

\begin{tabular}{llc}
\hline Kelompok ACT & $\begin{array}{l}\text { Kadar Periostin serum } \\
(\text { rerata } \pm \text { SD })\end{array}$ & $\begin{array}{c}\text { Nilai } \\
\mathbf{p}\end{array}$ \\
\hline $\begin{array}{l}\text { Terkontrol Sebagian } \\
\text { Tidak Terkontrol }\end{array}$ & $73,75 \pm 19,5$ \\
\hline
\end{tabular}

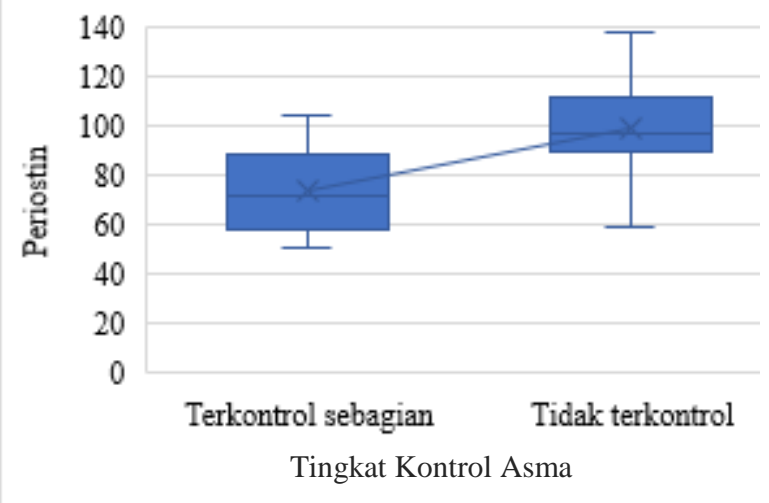

Gambar 1. Grafik perbandingan kadar periostin serum menurut tingkat kontrol asma

\section{PEMBAHASAN}

\section{Karakteristik subjek penelitian}

Selama periode penelitian mulai bulan Maret hingga Mei 2018 di Poli Asma/PPOK Dr. Soetomo Surabaya, didapatkan 40 subjek dengan karakteristik seperti terlihat pada tabel 1. Sebagian besar sampel berjenis kelamin perempuan $(65 \%)$ dengan mayoritas pekerjaan adalah ibu rumah tangga $(47,5 \%)$, hal ini dapat dikaitkan dengan ibu rumah tangga yang memiliki waktu bebas pada pagi dan siang hari sehingga memungkinkan untuk kontrol berobat di poli pada jam kerja. Menurut Riskesdas 2013, prevalensi asma cenderung lebih tinggi pada perempuan dibandingkan laki-laki. ${ }^{3}$ Weiss dan Apter mengungkapkan bahwa prevalensi asma didominasi oleh laki-laki pada usia anak-anak, prevalensi laki-laki dan wanita menjadi seimbang setelah pubertas, sedangkan pada usia tua terjadi pergeseran prevalensi di mana asma didominasi oleh wanita terutama setelah maenopause. ${ }^{12}$ Hal ini dapat disebabkan oleh adanya perubahan hormon estrogen yang mempengaruhi respons inflamasi jalan napas. Reseptor estrogen seperti ER $\alpha$, ER $\beta$, dan Gprotein couple receptor (GPR) memberikan signal Th2 dalam mensekresi IL-4, IL-5 dan IL-13. ${ }^{13}$

Profil umur penderita yang menjadi subjek penelitian adalah sekitar 18-55 tahun dengan rerata umur subjek penelitian 42,25 tahun, hampir mirip dengan studi oleh Emprm dkk dengan rerata umur sebesar 44,31 tahun. $^{7}$ Tingkat kontrol asma menunjukkan bahwa subjek lebih banyak pada asma tidak terkontrol, sebesar 34 (85\%). Hal ini sesuai dengan studi oleh Atmoko dkk yang menyatakan prevalensi asma tidak terkontrol sebanyak 81 orang $(75,7 \%)$ dari 107 sampel. ${ }^{14}$ Beberapa survei di negara berkembang menunjukkan bahwa sebagian besar penderita asma tidak mencapai kontrol asma yang adekuat, disebabkan oleh berbagai faktor seperti terdapat komorbiditas, resisten terhadap terapi, tidak adekuatnya pengobatan, terpajan faktor pencetus terus menerus, rendahnya kepatuhan terhadap terapi, dll. ${ }^{15}$

Kadar periostin serum menunjukkan bahwa rerata kadar periostin sebanyak 94,82 $\pm 19,21 \mathrm{ng} / \mathrm{ml}$, nilai median 94,7 ng/ml. Hasil ini lebih tinggi jika dibandingkan dengan studi oleh Matsusaka dkk dengan nilai median 70,00 ng/ml, tetapi lebih rendah jika dibandingkan median pada studi Amin dkk sebesar 140 ng/ml. ${ }^{16,} 17$ Studi Amin dkk juga memeriksa kadar periostin orang normal, didapatkan median $35 \mathrm{ng} / \mathrm{ml}$ dengan rentan 30-49 ng/ml. ${ }^{17}$ Pada studi didapatkan kadar periostin serum memiliki rentang yang luas bergantung pada karakteristik penderita dan reagen periostin yang dipergunakan. Belum ditentukan nilai batas untuk pengelompokkan periostin serum. ${ }^{17,}{ }^{18}$ Peneliti mengelompokkan kadar periostin serum berdasarkan metode tertil sesuai dengan kadar nilai periostin serum, sehingga didapatkan kelompok kadar periostin serum rendah, sedang, dan tinggi.

\section{Hubungan nilai ACT berdasarkan kelompok FEV 1}

Berdasarkan analisis statistik, didapatkan hubungan bermakna antara $\mathrm{FEV}_{1}$ dengan tingkat kontrol asma. Hal ini sesuai dengan teori yang menyatakan bahwa $\mathrm{FEV}_{1}$ yang rendah berkaitan dengan peningkatan risiko penurunan fungsi paru, sehingga mempengaruhi tingkat kontrol asma. Beberapa studi yang mengaitkan $\mathrm{FEV}_{1}$ dengan asma dapat dilihat pada penelitian Alvarez 
Gutierrez dkk. tahun 2010 yang menunjukkan adanya korelasi signifikan antara nilai $\mathrm{FEV}_{1}$ dengan tes kontrol asma. Penelitian Alvarez-Gutierrez dkk tahun 2010 diikuti oleh 441 pasien, didapatkan adanya hubungan yang signifikann antara $\mathrm{FEV}_{1}$ dan tingkat kontrol asma $(\mathrm{r}=0,19 ; \mathrm{p}<0,01){ }^{19}$

Penelitian oleh Ilyas dkk di RS Persahabatan tahun 2010, didapatkan hubungan antara ACT dan nilai spirometri secara statistik signifikan namun lemah $(\mathrm{r}=$ $0,382 ; \mathrm{p}<0,01)$. ACT dikatakan bermanfaat untuk melengkapi spirometri untuk menilai kontrol asma dan prognosis terapi. ${ }^{20}$ Hasil penelitian Vinh Nhu Nguyen dkk terhadap 323 pasien asma, didapatkan korelasi antara nilai ACT dan $\mathrm{FEV}_{1}(\mathrm{r}=0,35 ; \mathrm{p}<0,001)$. Menurut Vin Nhu Nguyen, nilai ACT berkorelasi baik dengan $\mathrm{FEV}_{1}$ dan untuk modifikasi terapi, sehingga dapat digunakan dalam praktek sehari-hari untuk membantu penilaian dalam terapi pasien asma. ${ }^{21}$ Berdasarkan hasil penelitian Atmoko dkk, terdapat hubungan bermakna antara derajat asma dengan tingkat kontrol asma, di mana semakin tinggi derajat berat asma maka semakin rendah tingkat kontrol asma. ${ }^{14}$

\section{Hubungan kadar periostin serum dan skor ACT pada penderita asma}

Inflamasi saluran napas dan aktivasi imun merupakan kunci utama etiopatogenesis asma dan sebagian besar penderita asma berespons baik dengan terapi asma yang berupa agonis $\beta 2$ dan kortikosteroid. Terdapat 5-10\% penderita yang tidak berespons dengan terapi ini. Diasumsikan bahwa respons yang kurang ini disebabkan oleh berbagai mekanisme yang mendasari, termasuk remodeling saluran napas. Pada penderita ini didapatkan kontrol yang buruk dengan gejala kronik, seringnya eksaserbasi, dan obstruksi saluran napas yang menetap walaupun sudah mendapat terapi. ${ }^{4}, 19$ Tingkat kontrol asma dapat dinilai dengan ACT. Nilai ACT merupakan kuesioner yang dapat dilakukan secara singkat, sederhana, mudah dilakukan sendiri, tersedia, serta memperlihatkan akurasi secara berkelanjutan. ${ }^{11}$

Pada beberapa studi sebelumnya, didapatkan bahwa periostin yang tinggi dihubungkan dengan inflamasi eosinofilik yang refrakter dan penurunan faal paru walaupun penderita sudah mendapat terapi kortikosteroid. Periostin dikatakan merupakan salah satu biomarker untuk menggambarkan respons yang rendah serta tidak sensitif terhadap kortikosteroid pada penderita asma. ${ }^{9,22}$ Seluruh sampel pada studi ini telah mendapatkan terapi asma berupa agonis $\beta 2$ dan kortikosteroid dengan tingkat kontrol asma sebagian besar didapatkan masih tidak terkontrol.

Pada penderita asma tidak terkontrol didapatkan nilai periostin serum lebih tinggi secara signifikan dibandingkan dengan penderita asma terkontrol sebagian $(98,54 \pm 16,9$ vs $73,75 \pm 19,5 ; p=0,024)$. Hal ini sesuai dengan studi oleh Kanemitsu dkk, didapatkan perbedaan signifikan antara nilai ACT pada penderita asma dengan periostin serum tinggi dibandingkan rendah $(p=0,02){ }^{23}$ Pada studi oleh Amin dkk juga didapatkan pada penderita asma tidak terkontrol, didapatkan nilai median periostin serum lebih tinggi dibandingkan asma terkontrol sebagian dan terkontrol (170 vs 140 vs 67,5; $p$ $=0,0001) \cdot{ }^{17}$ Sebaliknya, pada studi yang dilakukan oleh Matsusaka dkk, didapatkan bahwa nilai periostin serum dan ACT tidak terdapat hubungan yang signifikan $(\mathrm{p}=$ $0,53) .{ }^{16}$

Hal ini dapat disebabkan karena keterbatasan ACT. Keterbatasannya berupa beberapa penderita mungkin tidak merasakan gejala asma. Untuk penderita yang mungkin tidak merasakan gejala asma, maka sulit ditentukan berdasarkan skor ACT, pada kondisi tersebut dapat dideteksi dengan pemeriksaan faal paru. Selain itu, teknik pemeriksaan yang berbeda, yang mungkin dapat mempengaruhi hasil pemeriksaan, serta adanya faktor kelelahan, dapat mempengaruhi proses pembacaan. ${ }^{11}$ Schazts dkk menyatakan bahwa hanya dengan penilaian kontrol asma pada satu saat saja belum cukup untuk memberikan informasi dalam manajemen asma yang optimal. ${ }^{24}$

Penelitian Amin dkk menyatakan bahwa periostin serum menunjukkan peningkatan yang signifikan secara statistik pada kasus asma tidak terkontrol, obstruksi berat, peningkatan eosinofil sputum dan darah, resistensi steroid, serta adanya penyakit atopi lainnya. Peningkatan jumlah periostin yang persisten pada saluran napas berkontribusi pada mekanisme peningkatan remodeling saluran napas dan penurunan faal paru yang lebih besar. ${ }^{17}$

Ada beberapa kelemahan penelitian ini, di antaranya nilai periostin dinilai berdasakan tertil dari literatur dan tidak ada nilai periostin pada orang sehat, serta tidak dapat ditentukan kadar periostin serum pada pasien asma terkontrol penuh (tidak ada sampel pada penelitian ini).

\section{KESIMPULAN}

Didapatkan hubungan yang bermakna antara nilai ACT dan kadar periostin serum penderita asma. Kadar periostin tertinggi didapatkan pada kelompok asma tidak terkontrol, dengan nilai ACT yang lebih rendah.

\section{DAFTAR PUSTAKA}

1. Asthma GIF. Global Strategy for Asthma Management and Prevention. Global Initiative for Asthma, 2017.

2. Shifren A, Witt C, Christie C and Castro M. Mechanisms of Remodeling in Asthmatic Airways. Journal of Allergy. 2012; 2012: 316049.

3. Indonesia BPDPKKKR. Riset Kesehatan Dasar: Riskesdas 2013. Jakarta: Kementerian Kesehatan Republik Indonesia, 2013.

4. Luhadia SK. Steroid Resistant Asthma. The Journal of The Association of Physicians of India. 2014; 62: 38-40.

5. Barnes PJ. Pathophysiology of Asthma. British Journal of Clinical Pharmacology. 1996; 42: 3-10.

6. Izuhara K, Matsumoto H, Ohta S, Ono J, Arima K and Ogawa M. Recent Developments Regarding Periostin in Bronchial Asthma. Allergology International : Official Journal of the Japanese Society of Allergology. 2015; 64 Suppl: S3-10.

7. Emprm V, Rajanandh MG and Nageswari AD. Periostin A Novel Systemic Biomarker for Eosinophilic Airway 
Inflammation: A Case Control Study. J Clin Diagn Res. 2016; 10: Oc01-4.

8. Jia G, Erickson RW, Choy DF, et al. Periostin is a Systemic Biomarker of Eosinophilic Airway Inflammation in Asthmatic Patients. The Journal of Allergy and Clinical Immunology. 2012; 130: 647-54.E10.

9. Boushey H, Corry D and Fahy J. Asthma. In: Murray J, Nadel J and Mason R, (Eds.). Textbook of Respiratory Medicine. 3rd Edition Ed. Philadelphia: W.B. Saunders Company, 2004, P. 1168-216.

10. Fingleton J, Braithwaite I, Travers J, et al. Serum Periostin in Obstructive Airways Disease. The European Respiratory Journal. 2016; 47: 1383-91.

11. Thomas M, Kay S, Pike J, et al. The Asthma Control Test (ACT) as a Predictor of Gina Guideline-Defined Asthma Control: Analysis of a Multinational Cross-Sectional Survey. Primary Care Respiratory Journal : Journal of the General Practice Airways Group. 2009; 18: 41-9.

12. Weis $\mathbf{S}$ and Apter J. Asthma. In: Fishman A, Elias $\mathbf{J}$ and Grippi M, (Eds.). Fishman's Pulmonary Disease and Disorders. 4th Edition Ed. New York: McGraw-Hill Companies, 2008, P. 787-8.

13. De Nijs SB, Venekamp LN and Bel EH. Adult-Onset Asthma: Is It Really Different? European Respiratory Review : An Official Journal of the European Respiratory Society. 2013; 22: 44-52.

14. Atmoko W, Faisal HKP, Bobian ET, Adisworo MW and Yunus F. Prevalens Asma Tidak Terkontrol dan FaktorFaktor yang Berhubungan dengan Tingkat Kontrol Asma di Poliklinik Asma Rumah Sakit Persahabatan, Jakarta. Jurnal Respirologi Indonesia. 2011; 31: 53-60.

15. Chhabra SK. Assessment of Control in Asthma: The New Focus in Management. The Indian Journal of Chest Diseases \& Allied Sciences. 2008; 50: 109-16.

16. Matsusaka M, Kabata H, Fukunaga K, et al. Phenotype of Asthma Related with High Serum Periostin Levels.
Allergology International : Official Journal of the Japanese Society of Allergology. 2015; 64: 175-80.

17. Amin MM, Khattab MA, Hassan SA and Sattar HAA. Serum Periostin as a Unique Biomarker of Bronchial Asthma. Medical Journal of Cairo University. 2017; 85: 3285-93.

18. McSharry C and Johnstone S. Periostin as a Biomarker of Airway Inflammation. Polskie Archiwum Medycyny Wewnetrznej. 2016; 126: 118-20.

19. Álvarez-Gutiérrez FJ, Medina-Gallardo JF, Pérez-Navarro $\mathrm{P}$, et al. Relationship of the Asthma Control Test (ACT) with Lung Function, Levels of Exhaled Nitric Oxide and Control According to the Global Initiative for Asthma (Gina). Archivos de Bronconeumología ((English Edition)). 2010; 46: 370-7.

20. Ilyas M, Yunus F and Wiyono WH. Correlation between Asthma Control Test (ACT) and Spirometry as Tool of Assessing of Controlled Asthma. Jurnal Respirologi Indonesia. 2010; 30: 190-6.

21. Nguyen VN, Chavannes N, Le LT and Price D. The Asthma Control Test (ACT) as an Alternative Tool to Global Initiative for Asthma (GINA) Guideline Criteria for Assessing Asthma Control in Vietnamese Outpatients. Primary Care Respiratory Journal : Journal of the General Practice Airways Group. 2012; 21: 85-9.

22. Simpson JL, Yang IA, Upham JW, et al. Periostin Levels and Eosinophilic Inflammation in Poorly-Controlled Asthma. BMC Pulmonary Medicine. 2016; 16: 67.

23. Kanemitsu Y, Matsumoto H, Izuhara K, et al. Increased Periostin Associates with Greater Airflow Limitation in Patients Receiving Inhaled Corticosteroids. The Journal of Allergy and Clinical Immunology. 2013; 132: 305-12.E3.

24. Schatz M, Sorkness CA, Li JT, et al. Asthma Control Test: Reliability, Validity, and Responsiveness in Patients Not Previously Followed by Asthma Specialists. The Journal of Allergy And Clinical Immunology. 2006; 117: 549-56. 